\title{
Some comments on the (ab)use of sodium in garnet to predict eclogitic diamond potential
}

Grütter, H. S. and Quadling, K. E.

Anglo American Research Laboratories, P. O. Box 106, Crown Mines, 2025, South Africa

The association of high-sodium eclogitic garnets with diamonds was established as far back as 1971 when Sobolev and Lavrent'ev (1971) showed that garnets in diamond eclogite xenoliths and eclogitic garnets included in diamond contain $\geq 0.09$ to $0.22 \mathrm{wt} \% \mathrm{Na}_{2} \mathrm{O}$. These levels were found to surpass the $<0.07 \mathrm{wt} \% \mathrm{Na}_{2} \mathrm{O}$ in garnets from eclogites in lower pressure metamorphic complexes which "permit[s] one to suggest a possible dependence of the sodium admixture in garnets on pressure, fixed in this case by their association with diamond" (op. cit., p. 6). Following on this work, and that of McCandless and Gurney (1989), various authors have promulgated a threshold of $\geq 0.07$ wt $\% \mathrm{Na}_{2} \mathrm{O}$ in garnet to identify diamond-associated eclogitic garnets (e.g. Gurney et al., 1993; Fipke et al., 1995). This threshold has however been established through empirical observations, mostly on garnets included in diamonds, and is not particularly well constrained (see Gurney, 1984 and discussion in Gurney and Zweistra, 1995). In this contribution we consider data for graphite- or diamond-facies eclogites and show that eclogite bulk compositional controls effectively prevent delimitation of a sensible sodium-in-garnet threshold which uniquely characterises eclogite diamond-facies conditions.

Garnets in crustal and mantle eclogites display a wide range in composition and colour (e.g. Sobolev. 1977). The extreme chemical variation results from the high variance inherent in the two-, three-, or even four-phase assemblages that are common in most eclogites. Under such highvariance conditions mineral compositions should reflect bulk-rock chemistry at any given pressure and temperature (Goldschmidt, 1912; Weill and Fyfe, 1964), from which it is inferred that the chemistry of eclogitic minerals will vary anywhere along the univariant graphite-diamond equilibrium. This implies that the graphite-diamond equilibrium cannot be uniquely mapped into the chemical space occupied by eclogitic garnet. It follows that the $0.07 \mathrm{wt} \% \mathrm{Na}_{2} \mathrm{O}$-in-garnet threshold discussed above is probably not distinctive of diamond-facies conditions and that it should be tested reversibly before routine implementation. This test is conducted by comparing sodium levels in garnets from graphite- or diamond-bearing eclogite xenoliths. Published garnet analyses for such xenoliths exhibit the same $\mathrm{Na}_{2} \mathrm{O}-\mathrm{TiO}_{2}$ substitution vector that is known from eclogitic garnets included in diamond (not illustrated, but see Fig. 8 in Gurney et al., 1993) and the overwhelming majority of garnets in diamond-bearing eclogites have $\mathrm{Na}_{2} \mathrm{O} \geq 0.07 \mathrm{wt} \%$, in accordance with previous results (Table 1). However, it is evident that two-thirds of the garnets in graphite-only eclogites contain $\mathrm{Na}_{2} \mathrm{O} \geq 0.07 \mathrm{wt} \%$, reaching up to $0.16 \mathrm{wt} \% \mathrm{Na}_{2} \mathrm{O}$, and some garnets in. diamond-bearing eclogites contain almost no sodium (Table 1). The limits of the data listed in Table 1 suggest that "diamond-in" could occur at 0.02 wt $\% \mathrm{Na}_{2} \mathrm{O}$ in garnet, while "graphite-out" might occur at $0.19 \mathrm{wt} \% \mathrm{Na}_{2} \mathrm{O}$. The corresponding inter-quartile limits for the transition is 0.06 to $0.17 \mathrm{wt} \% \mathrm{Na}_{2} \mathrm{O}$ in garnet; which represents almost half of the entire range found in garnets from all mantle eclogite xenoliths! It is clear that $0.07 \mathrm{wt} \% \mathrm{Na}_{2} \mathrm{O}$ in garnet is neither distinctive nor characteristic of an eclogitic diamond association. 
Table 1: Summary statistics for $w t \% \mathrm{Na}_{2} \mathrm{O}$ in garnet from carbon-bearing eclogite xenoliths*

\begin{tabular}{|l|cccccc|}
\hline Carbon occurs as & Minimum & Maximum & Mean & St dev & $\mathrm{n}=$ & $\% \geq 0.07 \dagger$ \\
\hline Graphite & 0.00 & 0.16 & 0.080 & 0.043 & 56 & 66.1 \\
Graphite + Diamond & 0.08 & 0.19 & 0.119 & 0.039 & 12 & 100 \\
Diamond & 0.02 & 0.25 & 0.128 & 0.046 & 176 & 89.2 \\
\hline
\end{tabular}

* all analyses averaged per xenolith $\uparrow$ percentage of xenoliths with garnets that have $\geq 0.07 \mathrm{wt} \% \mathrm{Na}_{2} \mathrm{O}$.

Notwithstanding the comments made above, there is still some sense that can be made of the data in Table 1: mean (and maximum) $\mathrm{Na}_{2} \mathrm{O}$ in garnet increases in the classes graphite to graphite-plusdiamond to diamond eclogite, while the standard deviations remain almost identical. Students' Ttests indicate that the sodium contents in these classes are significantly different at the $99 \%$ level of confidence, implying that $\mathrm{wt} \% \mathrm{Na}_{2} \mathrm{O}$ in eclogitic garnet is without doubt positively correlated with the transition from graphite to diamond, and by inference, lithospheric depth. Since pressure and temperature both increase along conductive lithospheric geotherms, the sodium increase may reflect increasing $\mathrm{P}$ or $\mathrm{T}$, or both (see also Bishop et al., 1978). The validity of this inference can be confirmed by inspecting Fig. 1, in which an effort has been made to place carbon-bearing as well as carbon-free eclogite xenoliths within a broad-brush mantle stratigraphy by calculating their $\left(\mathrm{Fe}_{2} \mathrm{O}_{3}\right.$ free) garnet-clinopyroxene Fe-Mg exchange temperatures (after Krogh, 1988). A broad positive correlation between $\mathrm{Na}_{2} \mathrm{O}$ in eclogitic garnet and calculated temperature is clearly evident. The scatter in the relationship prohibits unique temperature (or depth) estimates to be made from the sodium content of the garnet, in effect implying that a wide variety of broadly basaltic bulk compositions may coexist as eclogites at typical mantle pressures and temperatures. If Fe-Mg equilibration is assumed, the relationship predicts a range of about 0 to $0.16 \mathrm{wt} \% \mathrm{Na}_{2} \mathrm{O}$ in garnet at temperatures typical of the graphite-diamond transition on cratonic geotherms $\left(950\right.$ to $\left.1050^{\circ} \mathrm{C}\right)$. This demonstrates, again, that sodium in garnet is not a particularly useful or distinctive measure of diamond-facies conditions in eclogites.

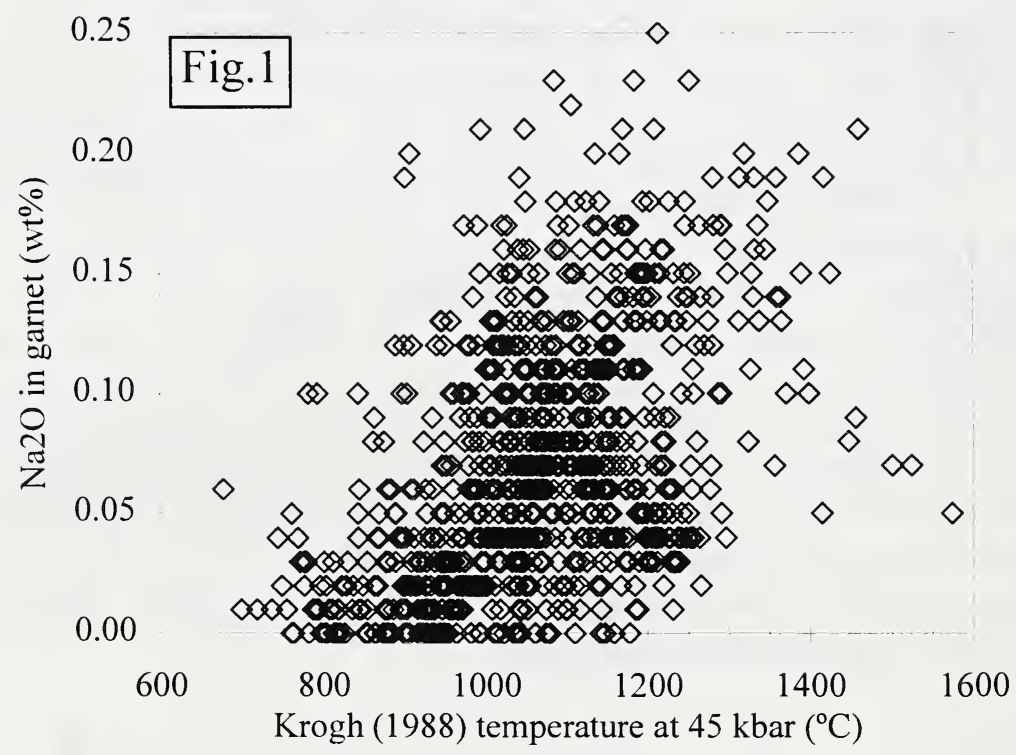




\section{References}

Bishop, F. C.. Smith, J. V. and Dawson, J. B., 1978, Na, K, P and Ti in garnet, pyroxene and olivine from peridotite and eclogite xenoliths from African kimberlites: Lithos 11, p. 155 - 173.

Fipke. C. E., Gurney, J. J. and Moore, R. O., 1995, Diamond exploration techniques emphasising indicator mineral geochemistry and Canadian examples: Geol. Surv. Canada Bull. 423, 86 pp.

Goldschmidt, V. M.. 1912, Ueber die anwendung der phasenregel auf die gezetse der mineralassoziation: Cetralblatt Mineral. Geol. Paleont., 1912, 574-576.

Gurney. J. J., 1984, A correlation between garnets and diamonds in kimberlites, in Glover. J. E. and Harris. P. G., eds., Kimberlite occurrence and origins: a basis for conceptual models in exploration: Geol. Dept. and Univ. Extension, Univ. of Western Australia Publ. 8, p. 143-166.

Gurney. J. J.. Helmstaedt, H. and Moore, R. O., 1993, A review of the use and application of mantle mineral geochemistry in diamond exploration: Pure and Appl. Chem., 65, p. 2423-2442.

Gurney, J. J. and Zweistra, P., 1995, The interpretation of the major element compositions of mantle minerals in diamond exploration: J. Geochem. Explor., 53, p. 293 - 309.

Krogh. E. J., 1988, The garnet-clinopyroxene Fe-Mg geothermometer - a reinterpretation of existing experimental data: Contrib. Mineral. Petrol., 99, 44-48.

McCandless, T. E. and Gurney, J. J., 1989, Sodium in garnet and potassium in clinopyroxene: criteria for classifying mantle eclogites, in Ross, J., ed., Kimberlites and related rocks: Geol. Soc. Australia Spec. Publ., 14, p. 827-832.

Sobolev, N. V., 1977, Deep-seated inclusions in kimberlites and the problem of the composition of the upper mantle: American Geophysical Union, Washington D.C., 279 pp.

Sobolev, N. V. and Lavrent'ev, J. G., 1971, Isomorphic sodium admixture in garnets formed at high pressures: Contrib. Mineral. Petrol., 31, p. 1 - 12.

Weill. D. F. and Fyfe, W. S., 1964. A discussion of the Korzhinskii and Thompson treatment of thermodynamic equilibrium in open systems: Geochim. Cosmochim. Acta, 28, p. 565-576. 